\title{
Native and alien herbaceous plants in the Brazilian Cerrado are (co-)limited by different nutrients
}

\author{
Luciola S. Lannes • Mercedes M. C. Bustamante • \\ Peter J. Edwards • Harry Olde Venterink
}

Received: 27 March 2015 / Accepted: 29 October 2015 / Published online: 10 November 2015

(C) Springer International Publishing Switzerland 2015

\begin{abstract}
Background and aims The diverse flora of the Brazilian Cerrado is threatened by agricultural expansion, nutrient enrichment and invasion of alien plants. We performed a fertilization experiment to investigate the nature of nutrient limitation in Cerrado vegetation, and evaluate whether native and alien invasive species are limited by the same or different nutrients.

Methods We applied various combinations of nutrients (phosphorus $(\mathrm{P})$, nitrogen $(\mathrm{N})$, and a mixture of other macro- and micro-nutrients ('cations treatment')) to six types of Cerrado vegetation. We then studied over a 3year period how these treatments affected the aboveground biomass of native forbs, native $\mathrm{C}_{3}$ and $\mathrm{C}_{4}$ grasses, and invasive $\mathrm{C}_{4}$ grasses.
\end{abstract}

Responsible Editor: Hans Lambers

L. S. Lannes · P. J. Edwards · H. Olde Venterink Institute of Integrative Biology, ETH Zürich, Universitätstrasse 16, 8092 Zürich, Switzerland

M. M. C. Bustamante

Departamento de Ecologia, Universidade de Brasília, Asa Norte, Brasília, DF, Brazil

L. S. Lannes $(\bowtie)$

Departamento de Biologia e Zootecnia, UNESP - Univ Estadual Paulista, Rua Monção 226, 15385-000 Ilha Solteira, SP, Brazil

e-mail: luciola.lannes@bio.feis.unesp.br

H. Olde Venterink

Plant Biology and Nature Management, Vrije Universiteit Brussel, Pleinlaan 2, 1050 Brussels, Belgium
Results The full nutrient treatment $(\mathrm{N}+\mathrm{P}+$ 'cations') significantly increased total community biomass across our sites, but $\mathrm{P}$ alone had no effect. The nutrient treatments also affected the relative abundance of functional plant groups in the six vegetation types. $\mathrm{P}$ addition, either alone or in combination with other nutrients, increased the biomass of alien $\mathrm{C}_{4}$ grasses, where present, whereas the cations treatment stimulated growth of the native $\mathrm{C}_{4}$ grasses. Addition of $\mathrm{N}+\mathrm{P}$ reduced the biomass of native $\mathrm{C}_{3}$ grasses.

Conclusions Our results indicate co-limitation by several nutrients, including $\mathrm{P}$, perhaps $\mathrm{N}$, and at least one other nutrient. Further research is needed to determine what the other nutrient (or nutrients) may be. Native and invasive species appear to be limited by different nutrients, with $\mathrm{P}$ alone stimulating growth of African $\mathrm{C}_{4}$ grasses. This should be considered in managing both natural and invaded communities.

Keywords Invasive grasses $\cdot$ Nutrient limitation $\cdot \mathrm{N}: \mathrm{P}$ ratio $\cdot$ Nutrients $\cdot$ Savanna $\cdot$ Stoichiometry

\section{Introduction}

During the past decade considerable progress has been made towards understanding the processes of mineral nutrient turnover within ecosystems, and how these affect community composition. In particular, international collaborations such as the NutNet network have developed standardized methods for comparing terrestrial ecosystems throughout the world (Adler et al. 2011), while 
meta-analyses based on studies from marine, freshwater and terrestrial ecosystems have demonstrated the importance of $\mathrm{N}$ and $\mathrm{P}$ as growth-limiting factors for primary production (Elser et al. 2007; Harpole et al. 2011). These comparative studies reveal that terrestrial ecosystems may be limited either by $\mathrm{N}$ or $\mathrm{P}$, with similar numbers of examples of each case, or jointly by both elements (Elser et al. 2007; Harpole et al. 2011). Although we might expect patterns of growth limitation to be different in temperate and tropical regions (Lambers et al. 2008), the existing data provide little evidence for latitudinal variation (Elser et al. 2007). However, the regional coverage of these studies is strongly biased towards Europe and North America (Elser et al. 2007), and there is a clear need for more fertilization experiments in regions that have been little studied.

One such region is the vast Brazilian Cerrado, which covers around $20 \%$ of the country and is the world's most species-rich savanna. The flora of this 'biodiversity hotspot' (Myers et al. 2000) comprises some 12,000 plant species, many of them endemic to the region, of which two thirds are herbaceous species or small shrubs (Mendonça et al. 2008). For various reasons, ecologists commonly assume that $\mathrm{P}$ is the most limiting nutrient for Cerrado plants; not only are the soils poor in mineral $\mathrm{P}$ and plants have low concentrations of $\mathrm{P}$ in their tissues (Batmanian and Haridasan 1985; Villela and Haridasan 1994), but many species exhibit P-conserving mechanisms (Nardoto et al. 2006; Kozovits et al. 2007). However, since the heavily-weathered Oxisols of Cerrado are usually poor in several other nutrients, including $\mathrm{N}$, potassium $(\mathrm{K})$, calcium $(\mathrm{Ca})$, magnesium $(\mathrm{Mg})$, sulphur (S) and various micronutrients (Haridasan 1992; Lilienfein et al. 2001; Goedert 1983), it is relevant to ask whether other nutrients are also sometimes limiting (or co-limiting).

The only study that appears to shed light on this question is that of Bustamante et al. (2012), who performed a fertilization experiment at a single site in Cerrado and found that different functional groups of plants were limited by different nutrients. Thus, $\mathrm{N}$ stimulated the growth of Echinolaena inflexa (the only known $\mathrm{C}_{3}$ grass in the Cerrado) while $\mathrm{P}$ or $\mathrm{N}+\mathrm{P}$ stimulated the growth of the alien invasive $\mathrm{C}_{4}$-grass Melinis minutiflora. Other native plants $\left(\mathrm{C}_{4}\right.$ grasses, sedges and forbs) in the experimental plots were negatively affected by these treatments, presumably because they increased the vigour of certain grasses. Indeed, one reason for the invasiveness of African $\mathrm{C}_{4}$ grasses such as Melinis minutiflora, Urochloa decumbens, Andropogon gayanus and Panicum maximum in South American savannas (Pivello et al. 1999) may be that they take up $\mathrm{N}$ more effectively than native species (Bilbao and Medina 1990).

The objectives of this study were: (i) to examine the type of nutrient limitation for herbaceous Cerrado vegetation, (ii) to evaluate whether different functional groups of plants $-\mathrm{C}_{4}$ grasses, $\mathrm{C}_{3}$ grasses, forbs, as well native and alien invasive species - are limited by different nutrients, and (iii) to investigate whether growth of invasive grasses can be a potential threat to Cerrado native species, and whether this threat is related to the availability of a particular nutrient (N, P or cations, or combinations of these).

Based upon previous studies in the Cerrado, we developed three hypotheses to be tested in our experiment: (1) biomass production of the total herbaceous community is primarily P-limited, (2) different functional groups are limited by different nutrients, with the native $\mathrm{C}_{3}$ grass Echinolaena inflexa being $\mathrm{N}$-limited and alien invasive $\mathrm{C}_{4}$ grasses being $\mathrm{P}$-limited (following Bustamante et al. 2012 and Lannes et al. 2012), and (3) following fertilization with its limiting nutrient, exotic invasive plants can outcompete Cerrado native functional groups. Hence, this is particularly expected upon Penrichment. We tested these hypotheses across six areas with differing vegetation and habitat conditions (see Methods for details) by applying various combinations of $\mathrm{P}, \mathrm{N}$, and a mixture of cations and micronutrients. We then monitored the responses of various functional groups of plants - native $\mathrm{C}_{4}$ and $\mathrm{C}_{3}$ grasses and forbs, alien invasive $\mathrm{C}_{4}$ grasses - over the following 3 years.

\section{Methods}

Experimental sites

The study was carried out between November 2007 and March 2010 in the Ecological Reserve of the IBGE (Brazilian Institute for Geography and Statistics, $<$ www.recor.org.br>), located $26 \mathrm{~km}$ south of Brasília, Brazil $\left(15^{\circ} 56^{\prime} \mathrm{S}, 47^{\circ} 53^{\prime} \mathrm{W}\right)$ at an elevation of $1100 \mathrm{~m}$ a.s. 1. The average annual precipitation during the experimental period was $1400 \mathrm{~mm}$, of which $90 \%$ fell in the wet season from October until April (Fig. 3).

The six areas we chose for the experiment differed from each other in ways that probably affected their nutrient status, such as severity of invasion, relative 
proportions of woody and herbaceous plants, abundance of legume trees, and fire frequency. One was chosen because it represented native vegetation containing a high abundance of invasive grasses. Two further areas represented a type of open shrubland vegetation known locally as campo sujo, one being an unburnt site and the other a frequently burnt site. Similarly, there were two areas in cerrado sensu stricto (shrubland) vegetation, one of which was also burnt and the other unburnt. In both cases, the unburnt sites were located inside the reserve and protected from fires, whereas the burnt sites were selected in a 'fire break' zone that has been burned annually for the last 25 years. The sixth area was selected because of the high abundance of $\mathrm{N}$-fixing trees, which could have enriched the soil with $\mathrm{N}$ and altered the type of nutrient limitation. Table 3 shows the initial vegetation composition of the plots. Below we describe each experimental area in detail:

Invaded open grassland (IOG) Natural patch of open grassland vegetation (referred as 'campo limpo' in Brazil) dominated by the most widespread invasive plants at the Cerrado, the grasses Melinis minutiflora and Urochloa decumbens.

Unburnt open shrubland (OS) and Burnt open shrubland (BOS) The open shrubland vegetation ('campo sujo') consists of continuous grassland with a shrub cover of around 10-15\% (Ribeiro and Walter 1998). The $O S$ site has been protected from fire for at least 19 years, whereas the BOS site has been burned annually for the last 25 years.

Shrubland (SS) and Burnt shrubland (BSS) These are typical cerrado vegetation areas ('cerrado sensu stricto'). As defined by Ribeiro and Walter (1998), this vegetation type consists of a continuous grass-forb basal cover scattered with 20-50\% cover of shrubs and trees up to $6 \mathrm{~m}$ tall. The $S S$ site had been protected from fire for at least 19 years, whereas the BSS site had been burned annually for the last 25 years.

Woodland dominated by legume trees (LEG) This area is located in a dense Cerrado vegetation ("cerrado denso') patch. In this vegetation type, tree canopy covers $50-70 \%$ of the terrain with trees reaching $8 \mathrm{~m}$ height on average. The area was dominated by the Papilionoideae trees Dalbergia miscolobium and Stryphnodendron adstringens.
Soil analyses showed that the control plots in the six areas had rather similar concentrations of extractable $\mathrm{N}$ and $\mathrm{P}$, except that ammonium concentrations were very low in BSS and SS sites (Table 4). The $L E G$ site had the lowest concentrations of extractable $\mathrm{P}$, but together with the $I O G$ site the highest concentrations of total P. Water content and total $\mathrm{N}$ were lowest at the burnt sites (BOS and $B S S$ ). Extractable $\mathrm{Mg}$ did not vary among sites. $B S S$, $S S$ and $L E G$ had the lowest concentrations of extractable Ca. Extractable K was highest in IOG and BSS.

Experimental design and fertilization treatments

In each of the six areas, we marked 30 plots of $1 \mathrm{~m}^{2}$ in open areas, i.e., excluding woody plants, separated from each other by a buffer zone of at least $1 \mathrm{~m}$. The experimental design was completely randomized, with six nutrient treatments and five replicates per treatment. Before the first fertilization, all herbaceous vegetation from all plots was clipped to $5 \mathrm{~cm}$ height. Plots were randomly assigned to one of six fertilization treatments: (1) unfertilized control, (2) N alone, (3) P alone, (4) N and P, (5) a combination of other macronutrients including the cations $\mathrm{K}, \mathrm{Ca}, \mathrm{Mg}$ and various micronutrients - hereafter called 'cations', and (6) all nutrients $(\mathrm{N}+\mathrm{P}+$ 'cations'). Nutrients were dissolved in 5 liters of tap water and gently applied to the soil surface of the plots for three growing seasons. Control plots received water without added nutrients. Forms and dosages of nutrients followed Cech et al. (2008) and are detailed in Appendix 4.

Sampling and analyses

We harvested the aboveground biomass from all 180 plots at the peak of the growing seasons (January or February) in 2008, 2009 and 2010. The harvested material was sorted into four functional groups: (i) alien invasive grasses (consisting of the $\mathrm{C}_{4}$ grasses Melinis minutiflora and Urochloa decumbens, the two most widely-distributed invaders at the Cerrado (Pivello et al. 1999; Almeida-Neto et al. 2010)), (ii) native $\mathrm{C}_{4}$ grasses (generally the most abundant component of uninvaded herbaceous Cerrado vegetation), (iii) the native $\mathrm{C}_{3}$ grass Echinolaena inflexa (the only $\mathrm{C}_{3}$ grass species known to be present in the Cerrado), and (iv) forbs. All samples were dried at $60{ }^{\circ} \mathrm{C}$ to constant weight, weighed and ground.

We analysed the data for the control plots to check whether repeated harvesting had any effect upon 
vegetation composition and biomass. Table 5 shows that in only one case $\left(\mathrm{C}_{3}\right.$ grasses at the BOS site) was there any significant change, this being an increase in biomass over the 3 years.

All biomass samples from the control and from the $\mathrm{N}+\mathrm{P}+$ 'cations' fertilized plots were analyzed for the major plant nutrients. Total $\mathrm{N}$ and $\mathrm{P}$ concentrations were determined by colorimetry (FIA Star, Foss Tecator Höganäs, Sweden) after Kjeldahl digestion. We calculated the contents of nutrients in the total vegetation as the sum of the products of the biomass fraction of each functional group by its respective tissue nutrient concentration.

Data analyses

To test how different fertilization treatments affected biomass production across sites, we used mixed models ANOVA using maximum likelihood as estimates with site as a random factor and treatment and year as factors. Each plot was included as a separate subject, with year as repeated measures. Nutrient treatment was included a single fixed factor with 6 levels (control, N, P, N+P, 'cations', $\mathrm{N}+\mathrm{P}+$ 'cations'), and Bonferroni post-hoc tests were used to check for significant differences between each of the five treatments and the controls. For responses of the functional groups to nutrient treatments we used the same overall model as described above, and included the biomass of complementary functional groups as covariates. To check for specific site effects on biomass, we included site as a fixed factor in this same model and performed separate analyses for each site in case of interaction between site and treatment. Interaction between treatment and time was checked with the same model.

Differences in relative abundance of the four functional groups in the phosphorus-fertilized plots compared to the control plots were tested by means of t-tests and assuming unequal variances. All analyses were performed using IBM SPSS 19 and 23.

\section{Results}

Total community biomass

At all sites, community biomass was higher under the full nutrient treatment $(\mathrm{N}+\mathrm{P}+$ 'cations') than under controls, with this effect tending to increase over time as indicated by a significant interaction between fertilization treatment and time (Fig. 1; Table 1; Fig. 4). At four sites (IOG,OS, BOS and BSS), the biomass was significantly higher at the end of the experiment (Tables 1 and 2). At another site the difference was significant only in 2008 ( $L E G$; Fig. 4). At one site, community biomass was also increased by a fertilizer treatment containing less than the full nutrient combination (BSS under $\mathrm{N}+\mathrm{P}+$ treatment) (Table 2). Phosphorus fertilization alone had no significant effect upon total aboveground vegetation biomass (Fig. 1; Table 2; Fig. 4).

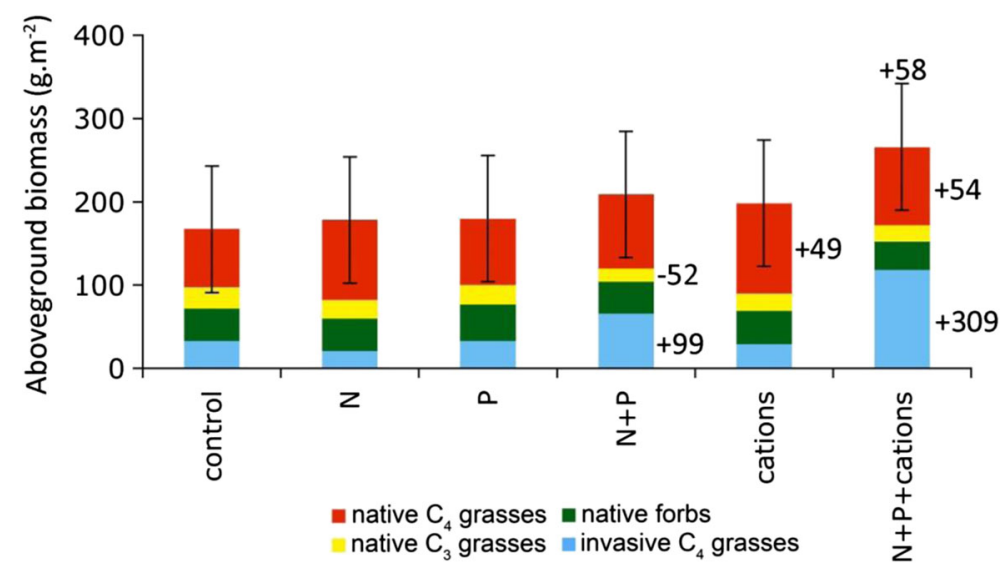

Fig. 1 Estimated marginal means for nutrient treatment effect on aboveground biomass averaged across six sites in the Cerrado. Error bars indicate $95 \%$ confidence interval of the mean for the total biomass values. Numbers indicate the percentage of biomass change promoted by the treatment in relation to the control plots when significant differences were found $(P<0.05)$, placed above the error bars for total biomass and indicated next to the respective sub-bar for the functional groups 
Table 1 Effects of nutrient treatments on total aboveground biomass, and biomasses of four functional groups across and within the six sampled sites over the 3 years of experiment. Data shown are F- and P-values of the overall effect of treatment and of the interaction between treatment and site and treatment and time on biomass. Results of separate analyses of the effect of treatment on biomass per site are also shown. Only plots containing the mentioned functional groups were included in the analyses. Biomasses of the other functional groups were included as covariates for the responses of the different functional groups. Significant differences resulting from Bonferroni post-hoc tests $(P<0.05)$ are indicated in Fig. 1 and Table 2

\begin{tabular}{|c|c|c|c|c|c|c|c|c|c|c|}
\hline & \multicolumn{2}{|c|}{ Total biomass } & \multicolumn{2}{|c|}{ Native forbs } & \multicolumn{2}{|c|}{ Native $C_{3}$ grasses } & \multicolumn{2}{|c|}{ Native $\mathrm{C}_{4}$ grasses } & \multicolumn{2}{|c|}{ Invasive $\mathrm{C}_{4}$ grasses } \\
\hline & $\mathrm{F}$ & $\mathrm{P}$ & $\mathrm{F}$ & $\mathrm{P}$ & $\mathrm{F}$ & $\mathrm{P}$ & $\mathrm{F}$ & $\mathrm{P}$ & $\mathrm{F}$ & $\mathrm{P}$ \\
\hline TREATMENT & 10.2 & $<0.001$ & 0.1 & 0.982 & 2.7 & 0.004 & 4.0 & 0.001 & 10.9 & $<0.001$ \\
\hline TREATMENT*SITE & 3.1 & $<0.001$ & 4.2 & $<0.001$ & 4.3 & $<0.001$ & 2.9 & $<0.001$ & 4.3 & $<0.001$ \\
\hline Invaded open grassland (IOG) & 5.5 & 0.001 & 3.7 & 0.005 & 4.2 & 0.026 & 1.8 & 0.132 & 14.0 & $<0.001$ \\
\hline Open shrubland (OS) & 2.7 & 0.024 & 2.4 & 0.043 & 1.5 & 0.042 & 2.8 & 0.019 & 5.7 & 0.001 \\
\hline Burned open shrubland (BOS) & 4.3 & 0.002 & 1.7 & 0.138 & 1.1 & 0.352 & 5.2 & $<0.001$ & - & - \\
\hline Burned shrubland (BSS) & 6.4 & $<0.001$ & 4.0 & 0.004 & 0.2 & 0.963 & 6.5 & $<0.001$ & - & - \\
\hline Shrubland (SS) & 1.6 & 0.168 & 0.9 & 0.462 & 1.9 & 0.009 & 2.1 & 0.078 & - & - \\
\hline Woodland dom. by leg. trees (LEG) & 1.1 & 0.348 & 0.4 & 0.858 & 1.1 & 0.367 & 2.1 & 0.083 & - & - \\
\hline TREATMENT*TIME & 6.1 & $<0.001$ & 0.4 & 0.928 & 1.5 & 0.133 & 2.6 & 0.003 & 15.9 & $<0.001$ \\
\hline
\end{tabular}

Table 2 Significant biomass mean differences $\left(\mathrm{g} . \mathrm{m}^{2}\right)$ between the nutrient treatments and the control plots and P-values resulting from Bonferroni post-hoc tests $(P<0.05)$ applied when significant interactions were found between treatment and site (Table 1).
Mean differences are based on estimated marginal means resulting from a mixed model with time as repeated measures and biomasses of the other functional groups included as covariates for the responses of the different functional groups

\begin{tabular}{|c|c|c|c|c|}
\hline Total biomass & Native forbs & Native $C_{3}$ grasses & Native $\mathrm{C}_{4}$ grasses & Invasive $\mathrm{C}_{4}$ grasses \\
\hline $\begin{array}{l}\text { Mean } \\
\text { difference }\end{array}$ & $\begin{array}{l}\text { Mean } \\
\text { difference }\end{array}$ & $\begin{array}{l}\text { Mean } \\
\text { difference }\end{array}$ & $\begin{array}{l}\text { Mean } \\
\text { difference }\end{array}$ & $\begin{array}{l}\text { Mean } \\
\text { difference }\end{array}$ \\
\hline
\end{tabular}

Invaded open grassland (IOG)

$\mathrm{P}$

$\mathrm{N}+\mathrm{P} \quad 139.3 \quad 0.001$

$-8.9 \quad 0.034$

112.4

0.020

89.3

0.041

$\mathrm{N}+\mathrm{P}+$ cations

137.5

$<0.001$

Open shrubland (OS)

$\mathrm{N}+\mathrm{P}$

$\begin{array}{llll}-9.5 & 0.024 & -18.1 & 0.017\end{array}$

Cations

$\mathrm{N}+\mathrm{P}+$ cations $\quad 173.0 \quad 0.005$

Burned open shrubland (BOS)

Cations

0.001

$\mathrm{N}+\mathrm{P}+$ cations $\quad 140.2$

Burned shrubland (BSS)

$\mathrm{P}$

$\mathrm{N}+\mathrm{P}$

62.7

0.009

$\mathrm{N}+\mathrm{P}+$ cations

86.7

$<0.001$

Shrubland (SS)

$\mathrm{N}+\mathrm{P}$

86.8

$<0.001$

$\begin{array}{ll}-14.8 & 0.031\end{array}$

$\begin{array}{ll}-14.8 & 0.031\end{array}$

$131.9 \quad 0.001$

$\begin{array}{rr}83.9 & 0.048 \\ 105.2 & 0.007\end{array}$

$\begin{array}{ll}-29.0 & 0.001\end{array}$ 
Functional groups of plants

The biomass of some native plants was reduced by fertilization, with the details varying according to treatment and functional group (Fig. 1; Tables 1 and 2). Overall, $\mathrm{N}+\mathrm{P}$ addition reduced the biomass of native $\mathrm{C}_{3}$ grasses, while at two sites (BSS and $\left.O S\right) \mathrm{P}$, alone or in combination with $\mathrm{N}$, reduced biomass of native forbs (Table 2). In contrast, the biomass of native $\mathrm{C}_{4}$ grasses increased following treatment with 'cations' or $\mathrm{N}+\mathrm{P}+$ 'cations'.

Only three of the six sites (IOG, OS, BOS) contained invasive $\mathrm{C}_{4}$ grasses. These species responded most strongly to the $\mathrm{P}$ treatment, whether applied alone or in combination with other nutrients $(\mathrm{N}+\mathrm{P}$ or $\mathrm{N}+\mathrm{P}+$ 'cations'; Table 2, Fig. 1; Fig. 4). In the IOG site, which was already heavily invaded at the start of the experiment, we observed that the timing of the response varied according the fertilizer treatment. In the first year, invasive plants only increased in biomass in the $\mathrm{N}+\mathrm{P}+$ 'cations' treatment, whereas in the second year they responded to the $\mathrm{N}+\mathrm{P}$ treatment, and in the third year also to the $\mathrm{P}$ alone treatment (Fig. 4). Similarly, in the $O S$ site, invasive grasses responded to the $\mathrm{N}+\mathrm{P}+$ 'cations' treatment in year two, and to $\mathrm{N}+\mathrm{P}$ in year three (Fig. 4). In the BOS site, where the invasion process had only recently begun, the grasses produced more biomass in response to the $\mathrm{P}, \mathrm{N}+\mathrm{P}$ and $\mathrm{N}+\mathrm{P}+$ 'cations' treatments (Fig. 4).

The relative dominance of invasive $\mathrm{C}_{4}$ grasses increased significantly with increasing soil $\mathrm{P}$ at $O S$ and BOS sites, at the expense of the native $\mathrm{C}_{3}$ grass Echinolaena inflexa (analysis confined to plots where invasive grasses were present; Fig. 2). No changes were recorded in the relative biomass of the native $\mathrm{C}_{4}$ grasses at any sites, but the proportions of forbs decreased at sites $S S$ and $B S S$.

\section{Discussion}

Co-limitation is the rule

Many native plant communities are known to be colimited by two and sometimes even more nutrients, with $\mathrm{N}$ and $\mathrm{P}$ being the commonest nutrients in short supply (Elser et al. 2007; Davidson and Howarth 2007; Harpole et al. 2011; Townsend et al. 2011; Fay et al. 2015). This

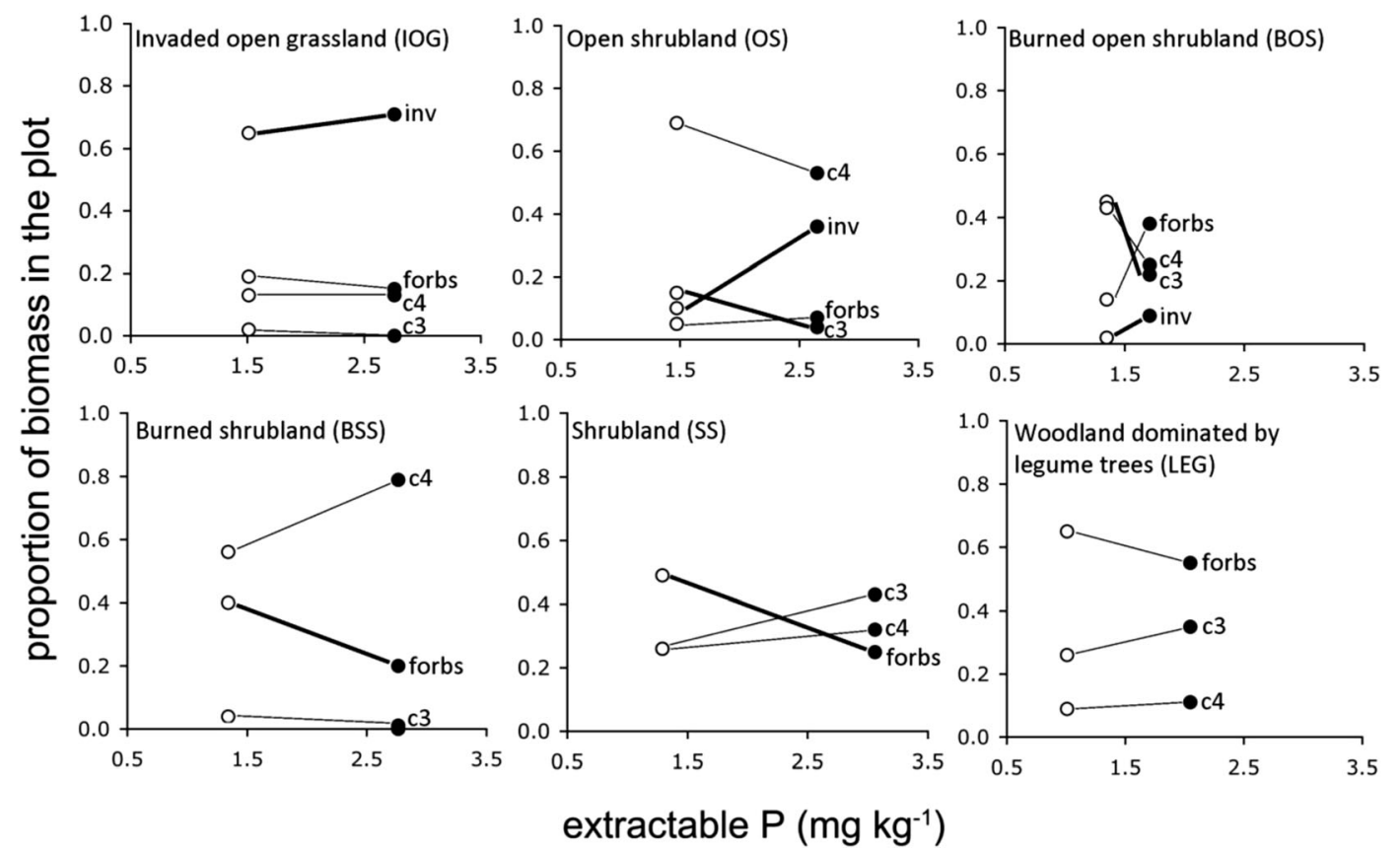

Fig. 2 Proportions of aboveground biomass of the four different functional groups (when present) in control plots (open circles) and $+\mathrm{P}$ plots (closed circles) in relation to extractable phosphorus in the soil for the six experimental sites in the last year of experiment (2010). Points were connected for a better visualization of the patterns. Significant changes in proportions $(t$-test, $P<0.05)$ are represented by bold lines. Label abbreviations mean: ' $c 4$ '- native $\mathrm{C}_{4}$ grasses; 'c3' - native $\mathrm{C}_{3}$ grasses; 'forbs' - native forbs; 'inv' invasive $\mathrm{C}_{4}$ grasses 
also appears to be the case in our study sites in Cerrado vegetation, where biomass only increased in response to treatments containing some combination of nutrients. Thus, our results do not support the usual assumption that plant growth in Cerrado is limited mainly by a shortage of P (Copeland et al. 2012; Olde Venterink 2011).

What makes our results unusual is that the nutrient combination needed to increase biomass included not only $\mathrm{N}$ and/or $\mathrm{P}$, but also one or more cations or micronutrients. This presumably reflects that fact that Cerrado soils are very ancient and highly weathered, and therefore poor in most plant nutrients. Indeed, colimitation by elements such as $\mathrm{K}, \mathrm{Ca}$ or $\mathrm{Mg}$ may be more common than previously supposed, especially in nutrient-poor soils, although this is often not considered in the design of fertilization experiments (but see Villela and Haridasan 1994; Bustamante et al. 2012; Fay et al. 2015). This might explain why $35 \%$ of the studies reviewed by Harpole et al. (2011) showed no response to nutrient addition (assuming that in many cases these other elements were not supplied).

The positive response of some native plants, particularly native $\mathrm{C}_{4}$ grasses, to the 'cations' treatment was also unexpected, and raises the question of which other element was actually limiting. Some South American savanna soils are known to be deficient in cations (Goedert 1983; Sarmiento et al. 1985), and the limiting nutrient could, in principle, have been any of the macroor micronutrients included in the mixture $(\mathrm{K}, \mathrm{Ca}, \mathrm{Mg}, \mathrm{S}$, $\mathrm{Fe}, \mathrm{Mn}, \mathrm{Zn}, \mathrm{B}, \mathrm{Cu}, \mathrm{Mo}$ and $\mathrm{Cl}$ ). However, some of these are more probable than others; for example, potassium (K) was shown to promote growth in Venezuelan savannas after $\mathrm{N}$ and $\mathrm{P}$ deficiencies were remedied (Tejos 1984; Barger et al. 2002; Sarmiento et al. 2006), and K limitation, or $\mathrm{K}$ co-limitation with $\mathrm{N}$ or $\mathrm{P}$, has also been reported for herbaceous plant communities elsewhere (van Duren and Petgel 2000; Olde Venterink et al. 2001, 2009; van de Riet et al. 2010; Fay et al. 2015). Calcium (Ca) and Magnesium (Mg), in contrast, were not a (co)limiting element in a fertilization experiment conducted in Cerrado vegetation near to our $S S$ site by Bustamante et al. (2012), and our 'cations' treatment also had no effect at that site. To clarify this issue, further experiments would be needed in which the various elements were added in different combinations.

For completeness, we note that our conclusions about $\mathrm{P}$ addition in this study could be biased by the fact that the $\mathrm{P}$ fertilizer raised soil $\mathrm{pH}$ from average values of 3.9-4.5 in the control plots to $4.5-5.1$ in the $+\mathrm{P}$ plots (data not shown). Although it is likely that the Paddition effect was more important than any effect due to altered $\mathrm{pH}$ (Crawley et al. 2005; Ceulemans et al. 2014), the latter cannot be excluded.

Native and alien species are limited by different nutrients

Plants of different origins appeared to be limited by different nutrients, with the invasive African $\mathrm{C}_{4}$ grasses being particularly responsive to $\mathrm{P}$ addition, while native $\mathrm{C}_{4}$ grasses responded more to the 'cations' treatment. This result is unexpected since both groups share the same growth form and photosynthetic pathway, while in previous studies similar differences in response have been associated with contrasting functional groups, e.g., $\mathrm{N}_{2}$-fixing and non-fixing species (Perreijn 2002; Suding et al. 2005). As shown by Bustamante et al. (2006), Cerrado soils are remarkably poor in extractable phosphorus, with values two orders of magnitude lower than other savannas in the world. The difference in growth limitation by the native $\mathrm{C}_{4}$ grasses from the Cerrado and alien African $\mathrm{C}_{4}$ grasses suggest that the former have adapted to these conditions of low $\mathrm{P}$ availability, while the latter perhaps have to cope with a very low supply of some other element. In support of this idea, Cerrado plants exhibit various root specializations (Oliveira et al. 2015), such as the exudation of carboxylates and mucilages demonstrated recently for a species of cactus (Abrahão et al. 2014).

Worldwide, there have been many reports of exotic plant invasions being promoted by enrichment with N (Daehler 2003; Cassidy et al. 2004; Tomassen et al. 2004; D'Antonio and Mack 2006; Siemann and Rogers 2007; Bobbink et al. 2010) or both $\mathrm{N}$ and $\mathrm{P}$ (de Oliveira et al. 2001; Huenneke et al. 1990), but far fewer in which the invasion was related to P enrichment (Daehler 2003). One such study is that of Bustamante et al. (2012), who demonstrated experimentally that $\mathrm{P}$ addition $\left(10 \mathrm{~g} . \mathrm{m}^{-2}\right)$ stimulated the spread of Melinis minutiflora in a Cerrado site. This is consistent with our finding that Melinis minutiflora and another invasive grass Urochloa decumbens increased when $\mathrm{P}\left(5 \mathrm{~g} \mathrm{~m}^{-2}\right)$ was added. It is also consistent with a previous study showing that these invasive African grasses have very low tissue $\mathrm{N}: \mathrm{P}$ ratios in the Cerrado, indicating conditions of relatively high $\mathrm{P}$ compared to $\mathrm{N}$ availability (Lannes et al. 2012). In fact, it is not surprising that 
these grasses respond strongly to nutrient addition, since they were deliberately introduced as forage species to Brazil for their high productivity under fertilized conditions (Pivello et al. 1999; Aires 2009). Other factors may also contribute to their high invasive potential in the Cerrado; for example, Melinis minutiflora produces very large numbers of seeds that can remain viable in the soil for an extended period (Carmona and Martins 2010), while Urochloa decumbens responds positively to fire (Pivello 2011). However, to understand their invasive behaviour in natural communities, it is important to know that it is $\mathrm{P}$ addition to which they respond most strongly.

In our experiment, the native plants showed either no response or a positive one to the cation treatment $\left(\mathrm{C}_{4}\right.$ grasses; see above), but they responded negatively to $\mathrm{P}$ and $\mathrm{N}+\mathrm{P}$ fertilization (forbs and $\mathrm{C}_{3}$ grass). In the 9years experiment of Bustamante et al. (2012), conducted at a site $150 \mathrm{~m}$ from our $S S$ site, the $\mathrm{C}_{3}$ grass Echinolaena inflexa was favoured by $\mathrm{N}$ addition $\left(10\right.$ g.m $\left.{ }^{-2}\right)$, whereas other native plants $\left(C_{4}\right.$ grasses, sedges, forbs) decreased due to competition from this species, or due to competition with the invasive $\mathrm{C}_{4}$ grass Melinis minutiflora following $\mathrm{P}$ or $\mathrm{P}+\mathrm{N}$ addition. Results from our sites only partially support these findings; for example, we found no positive effect of $\mathrm{N}$ enrichment $\left(20 \mathrm{~g} \mathrm{~m}^{-2}\right)$ on Echinolaena inflexa across our sites, and at one site it even decreased upon $\mathrm{N}+\mathrm{P}$ addition, although no invasive grasses were present ( $S S$ site). Similarly, the other native plants (particularly $\mathrm{C}_{4}$ grasses) generally benefited from the 'cations' treatment, and sometimes even declined when only $\mathrm{N}$ or $\mathrm{P}$ was applied where invasive $\mathrm{C}_{4}$ grasses were absent (BSS and $S S$ sites). These results highlight the complexity of plant responses to nutrient enrichment in the Cerrado, and suggest that the negative responses of native plants are not necessarily due to competition with invasive or other native plants, but may also be due to competition with soil microbes (cf. Ferreira et al. 2008).

Temporal changes in fertilizer response

In mixed vegetation, the addition of a growthlimiting resource typically stimulates one or more of the species already present, at least for a short while (Gough et al. 2000; Güsewell 2004). We observed this effect for total biomass across sites, where time positively interacted with treatment to define the observed patterns. Time also positively influenced biomass response of invasive species and native $\mathrm{C}_{4}$ grasses to fertilization. As indirect effects may only become evident gradually (Güsewell et al. 2002), longer-term experiments are needed to understand how increased nutrient supply will affect a plant community. Several mechanisms may have contributed to the timedependent response at our sites: (1) repeated nutrient additions might have been needed to exceed the effects of microbial immobilization or the high binding capacity of Cerrado soils for some nutrients (Chapin et al. 1986; Furley and Ratter 1988; DiTomasso and Aarssen 1989), (2) nutrients initially immobilized by microbes might have become available only after turnover of these organisms, and (3) the expansion or establishment of invading plant species and competitive replacement of initially present species under the fertilized conditions requires time.

Implications for conservation management

Our results show that invasive and native $\mathrm{C}_{4}$ grasses in the Cerrado are limited by different nutrients, and that $\mathrm{P}$ enrichment of the Cerrado can lead to the suppression of native $\mathrm{C}_{3}$ grasses by alien invasive grasses (Fig. 2). Exotic plants, such as Urochloa decumbens and Melinis minutiflora, occur in practically every Cerrado fragment (Pivello et al. 1999). As the largest agricultural area in Brazil, the Cerrado is subjected to levels of phosphorus fertilization (Goedert 1983) that often exceed agricultural demands (Sharpley et al. 2014) and threaten adjacent natural areas. Conservation of the extremely rich herbaceous flora therefore depends upon avoiding enrichment by preventing phosphorus runoff into the remaining patches of native vegetation. Additionally, stable soil and environmental conditions must be an important goal of any management regime since altered precipitation patterns, increased atmospheric $\mathrm{CO}_{2}$ concentrations and increased $\mathrm{N}$ deposition can all potentially increase soil $\mathrm{P}$ availability (Johnson et al. 1999; Zhang et al. 2012).

Acknowledgments This study was funded by the Swiss National Science Foundation (project 31003A_122563), ETH North South Centre and University of Brasilia. We thank the staff of IBGE Reserve for logistical support and Yann Hautier for helpful suggestions on a draft version of the manuscript. 


\section{Appendix 1}

Fig. 3 Monthly precipitation during the period of the experiment at the IBGE the IBGE meteorological station (http://www.recor.org.br) Ecological Reserve. Data from

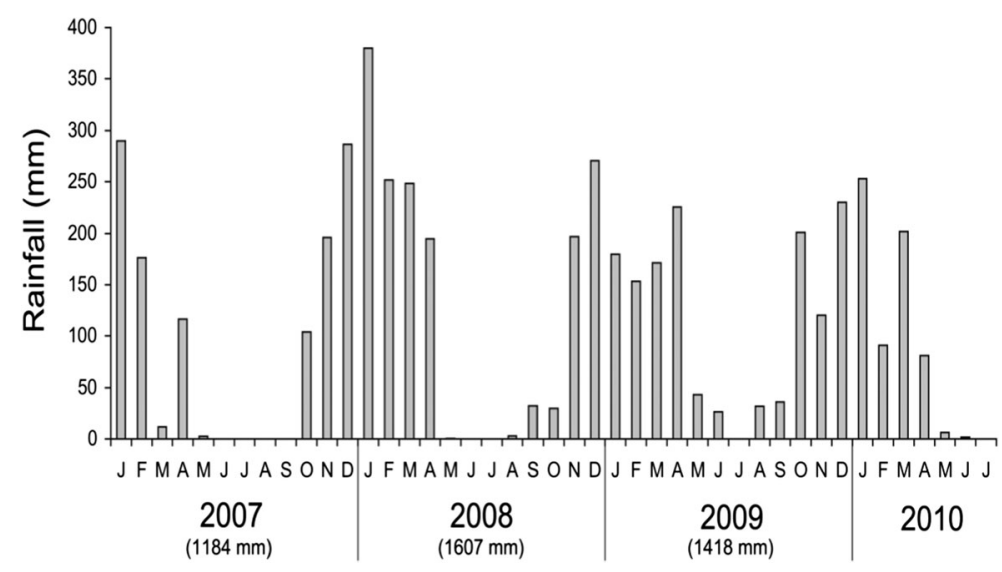

\section{Appendix 2}

Table 3 Number of plots per experimental site containing invasive $\mathrm{C}_{4}$ grasses, native forbs, native $\mathrm{C}_{3}$ grasses and invasive $\mathrm{C}_{4}$ grasses at the beginning of the experiment.

\begin{tabular}{lllll}
\hline & $\begin{array}{l}\text { Invasive } \mathrm{C}_{4} \\
\text { grasses }\end{array}$ & $\begin{array}{l}\text { Native } \\
\text { forbs }\end{array}$ & $\begin{array}{l}\text { Native } \mathrm{C}_{3} \\
\text { grasses }\end{array}$ & $\begin{array}{l}\text { Native } \mathrm{C}_{4} \\
\text { grasses }\end{array}$ \\
\hline $\begin{array}{l}\text { Invaded open grassland } \\
\text { Open shrubland }\end{array}$ & 29 & 24 & 4 & 20 \\
Burned open shrubland & 11 & 28 & 23 & 29 \\
$\begin{array}{l}\text { Burned shrubland } \\
\text { Shrubland }\end{array}$ & 0 & 28 & 29 & 30 \\
Woodland dominated by & 0 & 29 & 5 & 30 \\
$\quad$ legume trees & 0 & 30 & 30 & 30 \\
\hline
\end{tabular}

\section{Appendix 3}

Table 4 Soil characteristics for the six experimental sites used in this study. Differences were tested by means of ANOVA + Tukey test Averages and SE are shown. $n=3, P<0.05$

\begin{tabular}{|c|c|c|c|c|c|c|}
\hline & $\begin{array}{l}\text { Invaded open } \\
\text { grassland (IOG) }\end{array}$ & $\begin{array}{l}\text { Open shrubland } \\
\text { (OS) }\end{array}$ & $\begin{array}{l}\text { Burned open } \\
\text { shrubland (BOS) }\end{array}$ & $\begin{array}{l}\text { Burned } \\
\text { shrubland (BSS) }\end{array}$ & Shrubland (SS) & $\begin{array}{l}\text { Woodland dominated } \\
\text { by legume trees (LEG) }\end{array}$ \\
\hline $\mathrm{pH}_{\text {water }}$ & $4.49(0.11) \mathrm{a}$ & $4.08(0.03) b$ & $4.36(0.05) \mathrm{a}$ & $4.24(0.03) \mathrm{a}$ & $4.04(0.03) \mathrm{b}$ & $3.94(0.02) b$ \\
\hline Water content $(\%)$ & $29(1) b$ & $38(1) \mathrm{a}$ & $19(1) \mathrm{c}$ & 17 (1)a & $27(3) \mathrm{b}$ & $30(1) b$ \\
\hline Extractable P (mg/kg) & $1.51(0.06) \mathrm{a}$ & $1.47(0.07) \mathrm{a}$ & $1.35(0.01) \mathrm{a}$ & $1.34(0.03) \mathrm{a}$ & $1.29(0.07) \mathrm{a}$ & $1.01(0.07) \mathrm{b}$ \\
\hline $\begin{array}{l}\text { Extractable } \mathrm{N}^{-\mathrm{NH}_{4}}{ }^{+} \\
\quad(\mathrm{mg} / \mathrm{kg})\end{array}$ & $57.33(6.64) \mathrm{a}$ & $32.93(6.28) \mathrm{a}$ & $38.03(5.57) \mathrm{a}$ & $0.54(0.52) b$ & Not detected & $15.05(2.62) \mathrm{a}$ \\
\hline
\end{tabular}


Table 4 (continued)

\begin{tabular}{lllllll}
\hline & $\begin{array}{l}\text { Invaded open } \\
\text { grassland (IOG) }\end{array}$ & $\begin{array}{l}\text { Open shrubland } \\
(\mathrm{OS})\end{array}$ & $\begin{array}{l}\text { Burned open } \\
\text { shrubland (BOS) }\end{array}$ & $\begin{array}{l}\text { Burned } \\
\text { shrubland (BSS) }\end{array}$ & $\begin{array}{l}\text { Shrubland (SS) } \\
\text { Woodland dominated } \\
\text { by legume trees (LEG) }\end{array}$ \\
\hline $\begin{array}{l}\text { Extractable N-NO } \\
(\mathrm{mg} / \mathrm{kg})\end{array}$ & $16.23(0.15) \mathrm{a}$ & $7.99(1.91) \mathrm{a}$ & $9.45(2.88) \mathrm{a}$ & $9.80(2.84) \mathrm{a}$ & $8.22(0.14) \mathrm{a}$ & $12.62(1.89) \mathrm{a}$ \\
Total P $(\mathrm{mg} / \mathrm{kg})$ & $0.40(0.04) \mathrm{a}$ & $0.27(0.04) \mathrm{b}$ & $0.32(0.00) \mathrm{b}$ & $0.26(0.00) \mathrm{b}$ & $0.26(0.00) \mathrm{b}$ & $0.43(0.02) \mathrm{a}$ \\
Total N (mg/kg) & $3.12(0.14) \mathrm{ab}$ & $3.86(0.57) \mathrm{a}$ & $2.19(0.05) \mathrm{b}$ & $2.09(0.04) \mathrm{b}$ & $2.81(0.01) \mathrm{ab}$ & $2.67(0.22) \mathrm{ab}$ \\
Extractable K $(\mathrm{mg} / \mathrm{kg})$ & $26(4) \mathrm{a}$ & $15(3) \mathrm{b}$ & $17(2) \mathrm{b}$ & $27(2) \mathrm{a}$ & $14(1) \mathrm{b}$ & $14(2) \mathrm{b}$ \\
Extractable $\mathrm{Ca}(\mathrm{mg} / \mathrm{kg})$ & $139(8) \mathrm{a}$ & $142(9) \mathrm{a}$ & $148(5) \mathrm{a}$ & $112(6) \mathrm{b}$ & $102(3) \mathrm{b}$ & $97(3) \mathrm{b}$ \\
Extractable $\mathrm{Mg}(\mathrm{mg} / \mathrm{kg})$ & $38(12) \mathrm{a}$ & $29(2) \mathrm{a}$ & $30(2) \mathrm{a}$ & $31(1) \mathrm{a}$ & $24(2) \mathrm{a}$ & $24(1) \mathrm{a}$
\end{tabular}

At each experimental site, soil samples were collected in three randomly selected control plots. For each of these plots, three top-10 cm soil cores ( $5 \mathrm{~cm}$ diameter) were randomly collected and pooled to form a composite sample per plot. Nutrients were determined as follows

Extractable P: Colorimetrically, after extraction of dried soil samples with Mehlich I $\left(0.0125 \mathrm{M} \mathrm{H}_{2} \mathrm{SO}_{4}+0.05 \mathrm{M} \mathrm{HCl}\right)$

Extractable $\mathrm{N}_{-} \mathrm{NH}_{4}$ : Colorimetrically, through reaction with Nessler reagent, after extraction of fresh samples with $1 \mathrm{M} \mathrm{KCl} \mathrm{for} 1 \mathrm{~h}$

Extractable $\mathrm{N}_{-\mathrm{NO}_{3}}{ }^{-}$: Colorimetrically, through UV absorption according to Meier (1991), after extraction of fresh samples with $1 \mathrm{M} \mathrm{KCl}$ for $1 \mathrm{~h}$ Total $\mathrm{N}$ and total P: Colorimetrically, after Kjeldahl digestion

Extractable K, Ca and Mg: Atomic absorption spectrometry (SPECTRAA 240 FS, Varian), after extraction with 1 M ammonium acetate

\section{Appendix 4. Forms and dosages of nutrients applied in the fertilization plots.}

Control (control) - Water only.

Nitrogen $(\mathrm{N})-20 \mathrm{~g} \mathrm{~m}^{-2}$ of nitrogen supplied as $\mathrm{NH}_{4} \mathrm{NO}_{3}$.

Phosphorus (P) $-5 \mathrm{~g} \mathrm{~m}^{-2}$ of phosphorus supplied as $\mathrm{Na}_{2} \mathrm{HPO}_{4}$.

Nitrogen and phosphorus $(\mathrm{N}+\mathrm{P})$ - Simultaneous addition of nitrogen and phosphorus as described above.

Cations and micronutrients ('cations') - This treatment was applied to test whether other nutrient than $\mathrm{N}$ or
$\mathrm{P}$ was limiting growth. The combination of cations followed Cech et al. (2008). It consisted of $5 \mathrm{~g} \mathrm{~m}^{-2}$ of potassium $(\mathrm{KCl})+5 \mathrm{~g} \mathrm{~m}^{-2}$ of calcium $\left(\mathrm{CaCl}_{2} \cdot 2 \mathrm{H}_{2} \mathrm{O}\right)+$ $1.4 \mathrm{~g} \mathrm{~m}^{-2}$ of magnesium $\left(\mathrm{MgSO}_{4} .7 \mathrm{H}_{2} \mathrm{O}\right)+0.04 \mathrm{~g} \mathrm{~m}^{-2}$ of iron $\left(\mathrm{FeCl}_{2} \cdot 4 \mathrm{H}_{2} \mathrm{O}\right)+0.032 \mathrm{~g} \mathrm{~m}^{-2}$ of manganese $\left(\mathrm{MnCl}_{2} \cdot 4 \mathrm{H}_{2} \mathrm{O}\right)+0.012 \mathrm{~g} \mathrm{~m}^{-2}$ of zinc $\left(\mathrm{ZnSO}_{4} .7 \mathrm{H}_{2} \mathrm{O}\right)+$ $0.020 \mathrm{~g} \mathrm{~m}^{-2}$ of boron $\left(\mathrm{H}_{3} \mathrm{BO}_{3}\right)+0.016 \mathrm{~g} \mathrm{~m}^{-2}$ of copper $\left(\mathrm{CuSO}_{4} .5 \mathrm{H}_{2} \mathrm{O}\right)+0.002 \mathrm{~g} \mathrm{~m}^{-2}$ of molybdenum $\left(\mathrm{Na}_{2} \mathrm{MoO}_{4} \cdot 2 \mathrm{H}_{2} \mathrm{O}\right)$.

All nutrients $(\mathrm{N}+\mathrm{P}+$ 'cations') - Simultaneous addition of nitrogen, phosphorus and cations as described above.

\section{Appendix 5}

Table 5 Effects of 3 years of vegetation clipping on biomass of the control plots. F values and significance levels resulting from one-way ANOVA are shown. $N=5$. For $\mathrm{P}<0.05$, one significant value was detected (shown in bold)

\begin{tabular}{|c|c|c|c|c|c|c|c|c|c|c|}
\hline & \multicolumn{2}{|c|}{ Total biomass } & \multicolumn{2}{|c|}{ Invasive $\mathrm{C}_{4}$ grasses } & \multicolumn{2}{|c|}{ Native forbs } & \multicolumn{2}{|c|}{ Native $C_{3}$ grasses } & \multicolumn{2}{|c|}{ Native $C_{4}$ grasses } \\
\hline & $\mathrm{F}$ & Sig & $\mathrm{F}$ & Sig & $\mathrm{F}$ & Sig & $\mathrm{F}$ & Sig & $\mathrm{F}$ & Sig \\
\hline Invaded open grassland (IOG) & 1.90 & 0.200 & 0.89 & 0.441 & 1.07 & 0.379 & 0.79 & 0.480 & 0.48 & 0.630 \\
\hline Unburned open shrubland (OS) & 1.06 & 0.377 & 0.48 & 0.631 & 0.88 & 0.438 & 0.12 & 0.885 & 1.00 & 0.396 \\
\hline Burned open shrubland (BOS) & 2.13 & 0.162 & \multicolumn{2}{|c|}{ Appeared in 2010} & 3.01 & 0.087 & 5.68 & 0.018 & 0.23 & 0.798 \\
\hline Burned shrubland (BSS) & 2.03 & 0.174 & \multicolumn{2}{|c|}{ Absent } & 0.59 & 0.568 & 0.80 & 0.470 & 0.31 & 0.736 \\
\hline Shrubland (SS) & 1.19 & 0.337 & \multicolumn{2}{|c|}{ Absent } & 1.25 & 0.321 & 3.51 & 0.063 & 2.69 & 0.109 \\
\hline Woodland dominated by legume trees (LEG) & 0.99 & 0.401 & \multicolumn{2}{|c|}{ Absent } & 1.45 & 0.273 & 1.02 & 0.389 & 0.46 & 0.645 \\
\hline
\end{tabular}




\section{Appendix 6}

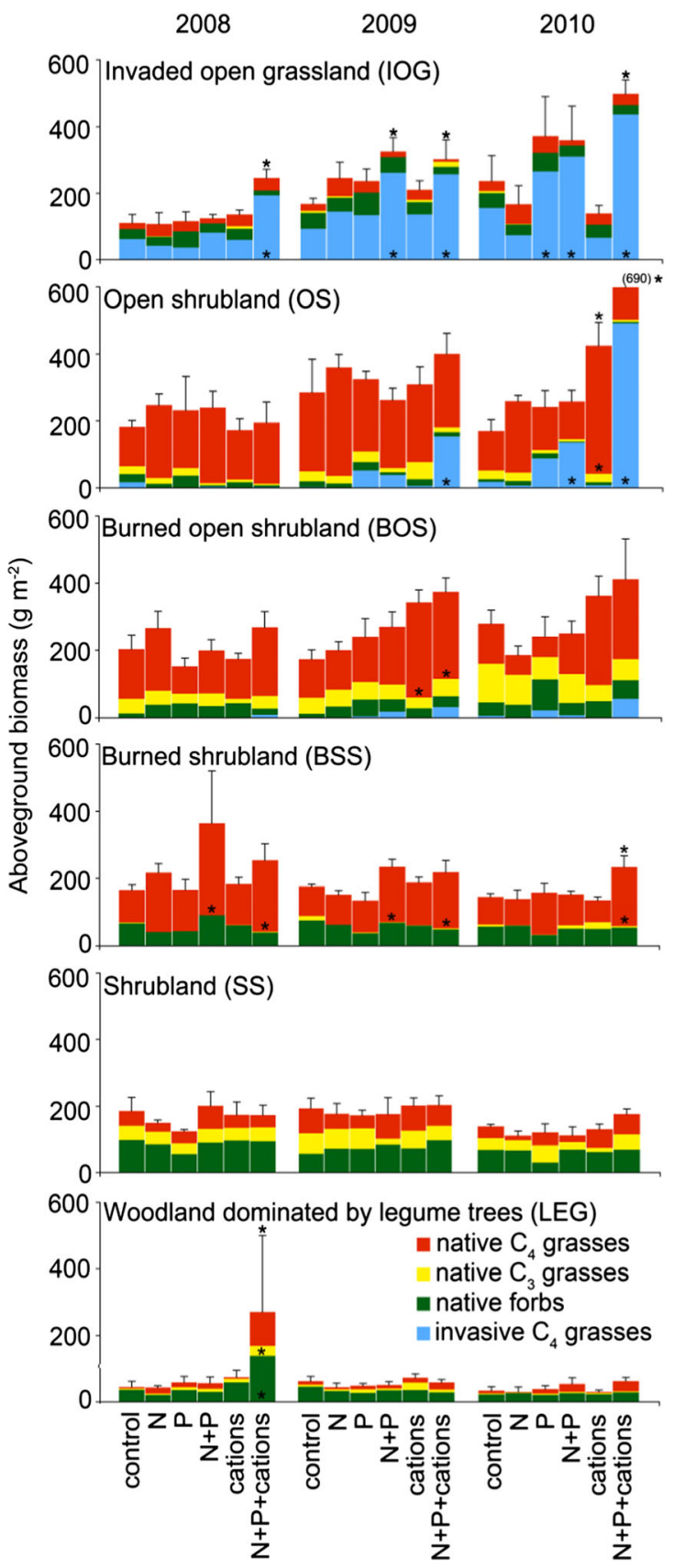

Fig. 4 Aboveground biomass responses to the six fertilization treatments in six sites in the Cerrado in the three years of experiment. The effects of nutrient additions on total biomass and biomass partitioned into functional groups were tested using ANOVA +2 -sided Dunnett test, $P<0.05$. Error bars correspond to the standard errors of the mean of total biomass $(n=5)$. Asterisks indicate significant differences between the treatments and control plots, placed above the error bars for total biomass and indicated in the respective sub-bar for the functional groups

\section{References}

Abrahão A, Lambers H, Sawaya ACHF, Mazzafera P, Oliveira RS (2014) Convergence of a specialized root trait in plants from nutrient-impoverished soils: phosphorus-acquisition strategy in a nonmycorrhizal cactus. Oecologia 176:345-355

Adler PB, Seabloom EW, Borer ET, Hillebrand H, Hautier Y, Hector H, HarpoleWS O'HLR, Grace JB, Anderson TM, Bakker JD, Biederman LA, Brown CS, Buckley YM, Calabrese LB, Chu C-J, Cleland EE, Collins SL, Cottingham KL, Crawley MJ, Damschen EI, Davies KF, DeCrappeo NM, Fay PA, Firn J, Frater P, Gasarch EI, Gruner DS, Hagenah N, Lambers JHR, Humphries H, Jin VL, Kay AD, Kirkman KP, Klein JA, Knops JMH, La Pierre KJ, Lambrinos JG, Li W, MacDougall AS, McCulley RL, Melbourne BA, Mitchell CE, Moore JL, Morgan JW, Mortensen B, Orrock JL, Prober SM, Pyke DA, Risch AC, Schuetz M, Smith MD, Stevens CJ, Sullivan LL, Wang G, Wragg PD, Wright JP, Yang LH (2011) Productivity is a poor predictor of plant species richness. Science 333:1750-1753

Aires FS (2009) Desenvolvimento de técnica de manejo, sem uso de agentes químicos, no controle da espécies invasora Melinis minutiflora Beauv. (capim-gordura) para aplicação em áreas de campo sujo. Master's thesis, Universidade de Brasília, Brasília

Almeida-Neto M, Prado PI, Kubota U, Bariani JM, Aguirre GH, Lewinsohn TM (2010) Invasive grasses and native Asteraceae in the Brazilian Cerrado. Plant Ecol 209:109-122

Barger NN, D'Antonio CM, Ghneim T, Brink K, Cuevas E (2002) Nutrient limitation to primary productivity in a secondary savanna in Venezuela. Biotropica 34:493-501

Batmanian GJ, Haridasan M (1985) Primary production and accumulation of nutrients by the ground layer community of cerrado vegetation of central Brazil. Plant Soil 88:437-440

Bilbao B, Medina E (1990) Nitrogen-use efficiency for growth in a cultivated African grass and a native South American pasture grass. J Biogeogr 17:421-425

Bobbink R, Hicks K, Galloway J, Spranger T, Alkemade R, Ashmore M, Bustamante M, Cinderby S, Davidson E, Dentener F, Emmett B, Erisman J-W, Fenn M, Gilliam F, Nordin A, Pardo L, de Vries W (2010) Global assessment of nitrogen deposition effects on terrestrial plant diversity: a synthesis. Ecol Appl 20:30-59

Bustamante MMC, Medina E, Asner GP, Nardoto GB, GarciaMontiel DC (2006) Nitrogen cycling in tropical and temperate savannas. Biogeochem 79:209-237

Bustamante MMC, de Britto DQ, Kozovits AR, Luedemann G, de Mello TRB, Pinto AS, Munhoz CBR, Takahashi FSC (2012) Effects of nutrient additions on plant biomass and diversity of the herbaceous-subshrub layer of a Brazilian savanna (Cerrado). Plant Ecol 213:795-808

Carmona R, Martins CR (2010) Dormência e armazenabilidade de sementes de capim-gordura. Revista Brasileira de Sementes 32(4):71-79

Cassidy TM, Fownes JH, Harrington RA (2004) Nitrogen limits an invasive perennial shrub in forest understory. Biol Inv 6: 113-121

Cech PG, Kuster T, Edwards PJ, Olde VH (2008) Effects of herbivory, fire and $\mathrm{N}_{2}$-fixation on nutrient limitation in a humid African savanna. Ecosystems 11:991-1004 
Ceulemans T, Stevens CJ, Duchateau L, Jacquemyn H, Gowing DJG, Merckx R, Wallace H, van Rooijen N, Goethem T, Bobbink R, Dorland E, Gaudnik C, Alard D, Corcket E, Muller S, Dise NB, Dupré C, Dieckmann M, Honnay O (2014) Soil phosphorus constrains biodiversity across European grasslands. Global Change Biology doi: $1<$ $0.0010 /$ gcb. 12650

Chapin FS, Vitousek PM, van Cleve K (1986) The nature of nutrient limitation in plant communities. Am Nat 127:48-58

Copeland SM, Bruna EM, Barbosa Silva LV, Mack MC, Vasconcelos HL (2012) Short-term effects of elevated precipitation and nitrogen on soil fertility and plant growth in a Neotropical savanna. Ecosphere 3(4):31

Crawley MJ, Johnston AE, Silvertown J, Dodd M, Mazancourt C, Heard MS, Henman DF, Edwards GR (2005) Determinants of species richness in the Park Grass experiment. Am Nat 165(2):179-192

D'Antonio CM, Mack MC (2006) Nutrient limitation in a firederived, nitrogen-rich Hawaiian grassland. Biotropica 38: 458-467

Daehler CC (2003) Performance comparisons of co-occurring native and invasive grasses: implications for conservation and restoration. Ann Rev Ecol Evol Syst 34:183-211

Davidson EA, Howarth RW (2007) Nutrients in synergy. Nature 449:1000-1001

de Oliveira OC, de Oliveira IP, Ferreira E, Alves BJR, Miranda CHB, Vilela L, Urquiaga S (2001) Response of degraded pastures in the Brazilian cerrado to chemical fertilisation. Pasturas Tropicales 23:14-18

DiTomasso A, Aarssen LW (1989) Resource manipulations in natural vegetation: a review. Vegetatio 84:9-29

Elser JJ, Bracken MES, Cleland EE, Gruner DS, Harpole WS, Hillebrand H, Ngai JT, Seabloom EW, Shurin JB, Smith JE (2007) Global analysis of nitrogen and phosphorus limitation of primary producers in freshwater, marine and terrestrial ecosystems. Ecol Lett 10:1135-1142

Fay PA, Prober SM, Harpole WS, Knops JMH, Bakker JD, Borer ET, Lind EM, MacDougall AS, Seabloom EW, Wragg PD, Adler PB, Blumenthal DM, Buckley YM, Chu C, Cleland EE, Collins SL, Davies KF, Du G, Feng X, Firn J, Gruner DS, Hagenah N, Hautier Y, Heckman RW, Jin VL, Kirkman KP, Klein J, Ladwig LM, Li Q, McCulley RL, Melbourne BA, Mitchell CE, Moore JL, Morgan JW, Risch AC, Schütz M, Stevens CJ, Wedin DA, Yang LH (2015) Grassland productivity limited by multiple nutrients. Nature Plants 1:1-5

Ferreira AS, de Oliveira RS, dos Santos MA, Borges EN (2008) Atividade respiratória da microbiota e conteúdo de glicose em resposta à adição de fósforo em solo de Cerrado. Revista Brasileira de Ciência do Solo 32:1891-1897

Furley PA, Ratter JA (1988) Soil resources and plant communities of the central Brazilian Cerrado and their development. J Biogeogr 15(1):97-108

Goedert WJ (1983) Management of the Cerrado soils of Brazil: a review. J Soil Sci 34:405-428

Gough L, Osenberg CW, Gross KL, Collins SL (2000) Fertilization effects on species density and primary productivity in herbaceous plant communities. Oikos 89:428-439

Güsewell S (2004) N:P ratios in terrestrial plants: variation and functional significance. New Phytol 164:243-266
Güsewell S, Koerselman W, Verhoeven JTA (2002) Timedependent effects of fertilization on plant biomass in floating fens. J Veg Sci 13:705-718

Haridasan M (1992) Observations on soils, foliar nutrient concentrations and floristic composition of cerrado sensu stricto and cerradao communities in Central Brazil. In: Furley PA, Ratter JA (eds) Nature and dynamics of forest-savanna boundaries. Chapman \& Hall, London

Harpole WS, Ngai JT, Cleland EE, Seabloom EW, Borer ET, Bracken MES, Elser JJ, Gruner DS, Hillebrand H, Shurin JB, Smith JE (2011) Nutrient co-limitation of primary producer communities. Ecol Lett 14:852-862

Huenneke LF, Hamburg SP, Koide R, Mooney HA, Vitousek PM (1990) Effects of soil resources on plant invasion and community structure in Californian serpentine grassland. Ecology 71:478-491

Johnson D, Leake JR, Lee JA (1999) The effects of quantity and durations of simulated pollutant nitrogen deposition on rootsurface phosphatase activities in calcareous and acid grasslands: a bioassay approach. New Phyt 141:433-442

Kozovits AR, Bustamante MMC, Garofalo CR, Bucci S, Franco AC, Goldstein G, Meinzer FC (2007) Nutrient resorption and patterns of litter production and decomposition in a Neotropical Savanna. Funct Ecol 21:1034-2043

Lambers H, Raven JA, Shaver GR, Smith SE (2008) Plant nutrient-acquisition strategies change with soil age. Trends Ecol Evol 23:95-103

Lannes LS, Bustamante MMC, Edwards PJ, Olde Venterink H (2012) Alien and endangered plants in the Brazilian Cerrado exhibit contrasting relationships with vegetation biomass and N:P stoichiometry. New Phytol 196:816-823

Lilienfein J, Wilcke W, Zimmermann R, Gerstberger P, Araujo GM, Zech W (2001) Nutrient storage in soil and biomass of native Brazilian Cerrado. J Plant Nutr Soil Sci 164:487-495

Meier M (1991) Nitratbestimmung in Boden-Proben (N-minMethode). LaborPraxis, Berlin

Mendonça RC, Felfili JM, Walter BMT, Silva Júnior MC, Rezende AV, Filgueira JS, Nogueira PE (2008) Flora vascular do cerrado: um 'checklist' com 11.430 espécies. In: Sano SM, Almeida SP, Ribeiro JF (eds) Cerrado ambiente e flora, 2nd edn. Embrapa Informação Tecnológica, Brasília

Myers N, Mittermeier RA, Mittermeier C, da Fonseca GAB, Kent J (2000) Biodiversity hotspots for conservation priorities. Nature 403:853-858

Nardoto GB, Bustamante MMC, Pinto AS, Klink CA (2006) Nutrient use efficiency at ecosystem and species level in savanna areas of Central Brazil and impacts of fire. J Trop Ecol 22:191-201

Olde Venterink H (2011) Does phosphorus limitation promote species-rich plant communities? Plant Soil 345:1-9

Olde Venterink H, van der Vliet RE, Wassen MJ (2001) Nutrient limitation along a productivity gradient in wet meadows. Plant Soil 234:171-179

Olde Venterink H, Kardel I, Kotowski W, Peeters WHM, Wassen MJ (2009) Long-term effects of drainage and hay-removal on nutrient dynamics and limitation in the Biebrza mires, Poland. Biogeochem 93:235-252

Oliveira RS, Galvão HC, de Campos MCR, Eller CB, Pearse SJ, Lambers H (2015) Mineral nutrition of campos rupestres plant species on contrasting nutrient-impoverished soil types. New Phytol 205:1183-1194 
Perreijn K (2002) Symbiotic nitrogen fixation by leguminous trees in tropical rain forest in Guyana. $\mathrm{PhD}$ thesis, Universiteit Utrecht, Utrecht

Pivello VR (2011) Invasões biológicas no Cerrado brasileiro: Efeitos da introdução de espécies exóticas sobre a biodiversidade. ECOLOGIA.INFO 33

Pivello VR, Shida CN, Meirelles ST (1999) Alien grasses in Brazilian savannas: a threat to biodiversity. Biodivers Conserv 8:1281-1294

Ribeiro JF, Walter BMT (1998) Fitofisionomias do bioma Cerrado. In: Sano SM, Almeida SP (eds) Cerrado: ambiente e flora. Embrapa CPAC, Planaltina

Sarmiento G, Goldstein G, Meinzer F (1985) Adaptive strategies of woody species in neotropical savannas. Biol Rev 60:315355

Sarmiento G, da Silva MP, Naranjo ME, Pinillos M (2006) Nitrogen and phosphorus as limiting factors for growth and primary production in a flooded savanna in the Venezuelan Llanos. J Trop Ecol 22:203-212

Sharpley A, Jarvie HP, Buda A, May L, Spears B, Kleinman P (2014) Phosphorus legacy: overcoming the effects of past management practices to mitigate future water quality impairment. J Environ Qual 42:1308-1326

Siemann E, Rogers WE (2007) The role of soil resources in an exotic tree invasion in Texas coastal prairie. J Ecol 95:689697
Suding KN, Collins SL, Gough L, Clark C, Cleland EE, Gross KL, Milchunas DG, Pennings S (2005) Functional- and abundance-based mechanisms explain diversity loss due to N fertilization. Proc Natl Acad Sci U S A 102:4387-4392

Tejos R (1984) Efecto del potasio y azufre sobre el pastizal nativo de una sabana. I. Producción. Zootec Trop 2:74-89

Tomassen HBM, Smolders AJP, Limpens J, Lamers LPM, Roelofs JGM (2004) Expansion of invasive species on ombrotrophic bogs: dessication or high N deposition? J Appl Ecol 41:139150

Townsend AR, Cleveland CC, Houlton BZ, Alden CB, White JWC (2011) Multi-element regulation of the tropical forest carbon cycle. Front Ecol Environ 9(1):9-17

van de Riet BP, Barendregt A, Brouns K, Hefting MM, Verhoeven JTA (2010) Nutrient limitation in species-rich Calthion grasslands in relation to opportunities for restoration in a peat meadow landscape. Appl Veg Sci 13:315-325

van Duren IC, Petgel DM (2000) Nutrient limitations in wet, drained and rewetted fen meadows: evaluation of methods and results. Plant Soil 220:35-47

Villela DM, Haridasan M (1994) Response of the ground layer community of a cerrado vegetation in central Brazil to liming and irrigation. Plant Soil 163:25-31

Zhang ZJ, Wang ZD, Holden J, Xu XH, Wang H, Ruan JH, Xu H (2012) The release of phosphorus from sediment into water in subtropical wetlands: a warming microcosm experiment. Hydrol Process 26(1):15-26 